\title{
Bending strength and reliability of porcelains used in all-ceramic dental restorations
}

\section{(Resistência à flexão e confiabilidade de porcelanas usadas em restaurações dentárias totalmente cerâmicas)}

\author{
A.A. de Almeida Junior ${ }^{1}$, G. L.Adabo ${ }^{1^{*}}$, B. R. Galvão ${ }^{1}$, D. Longhini ${ }^{1}$, B. G. Simba ${ }^{2}$, C. dos Santos ${ }^{3}$ \\ ${ }^{I}$ Universidade Estadual Paulista - UNESP, Faculdade de Odontologia de Araraquara, \\ R. Humaitá 1740, 14801-930, Araraquara, SP, Brazil \\ ${ }^{2}$ Universidade Estadual Paulista - UNESP, Faculdade de Engenharia de Guaratinguetá, Guaratinguetá, SP, Brazil \\ ${ }^{3}$ Universidade do Estado do Rio de Janeiro, Faculdade de Tecnologia, Resende, RJ, Brazil
}

\begin{abstract}
Four dental porcelains for covering zirconia were sintered (fired) at $910-960{ }^{\circ} \mathrm{C}$ and characterized, focusing in analyzing reliability, physical and mechanical properties. Samples with relative density close to $99 \%$ presented leucite crystallization apart from residual amorphous phase. Hardness between $491 \pm 23$ and $575 \pm 32$ HV was different among all ceramics. Fracture toughness between $1.13 \pm 0.11$ and $1.42 \pm 0.25 \mathrm{MPa} \cdot \mathrm{m}^{1 / 2}$ was statistically different. Bending strength results were not different for three porcelain groups $(73 \pm 9$ to $75 \pm 12 \mathrm{MPa})$, with the exception of one specific group $(62 \pm 4 \mathrm{MPa})$. Weibull analysis indicated bending strength between 73 and $75 \mathrm{MPa}$, Weibull modulus $(\mathrm{m})$ between 5.7 and 7.1, while the ceramic with strength of $60 \mathrm{MPa}$ presented $\mathrm{m}=13.6$. The use of classical theory of fracture mechanics associated to the results of properties obtained in this work indicated the critical failure size in these ceramics lays between 65 and $90 \mu \mathrm{m}$ and the theoretical fracture energy of porcelains is approximately from 10.5 to 16.3 $\mathrm{J} / \mathrm{m}$. It was concluded that the porcelains had different behavior, and it seems that there is no clear relationship among the studied properties.
\end{abstract}

Keywords: metal-free systems, fixed dental prostheses (FDPs), veneering ceramics, mechanical properties.

Resumo

Quatro porcelanas dentárias para cobertura de zircônia foram sinterizadas (queimadas) a 910-960 ${ }^{\circ} \mathrm{C}$ e caracterizadas, focando na análise de confiabilidade, propriedades físicas e mecânicas. Amostras com densidade relativa próxima de $99 \%$ apresentaram cristalização de leucita, além de fase amorfa residual. Dureza entre $491 \pm 23$ e $575 \pm 32$ HV foi diferente entre todas as cerâmicas.

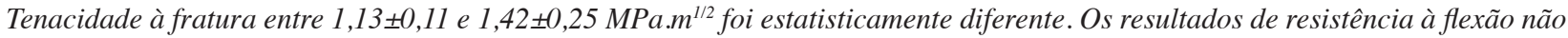
foram diferentes para as porcelanas ( $73 \pm 9$ a $75 \pm 12 \mathrm{MPa}$ ), com a exceção de um grupo específico (62 $\pm 4 \mathrm{MPa}$ ). A análise de Weibull indicou resistência à flexão entre 73 e $75 \mathrm{MPa}$, módulo de Weibull $(\mathrm{m})$ entre 5,7 e 7,1, enquanto a cerâmica com resistência de $60 \mathrm{MPa}$ apresentou $m=13,6.0$ uso de teoria clássica da mecânica da fratura, associado aos resultados das propriedades obtidas neste trabalho, indicou tamanho crítico do defeito nestas cerâmicas entre 65 e 90 um e a energia de fratura teórica das porcelanas foi de 10,5 a 16,3 J/m. Concluiu-se que as porcelanas têm diferentes comportamentos e parece não haver clara relação entre as propriedades estudadas.

Palavras-chave: sistemas livres de metal, prótese parcial fixa, cerâmicas de cobertura, propriedades mecânicas.

\section{INTRODUCTION}

The 'metal free' dental systems are based in different structural ceramics, such as $\mathrm{ZrO}_{2}\left(\mathrm{Y}_{2} \mathrm{O}_{3}\right)$, for development of fixed dental prostheses (FDPs) [1, 2]. Due to high opacity, these materials are usually coated with feldspathic ceramics, which as reconstructive material has as a role to meet dental prostheses aesthetic requirements. However, covering porcelains are fragile materials with lower mechanical resistance when compared to zirconia [3]. One of the main problems found in ceramics for dental prosthesis manufacturing is related to the large dispersion of values in mechanical property testing as fracture toughness and modulus of rupture (bending strength), which leads to a decrease in the reliability of these materials $[1,3]$. The achievement of consistent data about bending strength is complex compared to ductile metals, due to wellknown fragility and their statistic characteristic of failure distribution (positions, size and shapes of these failures) in the ceramic structures. Thus, some statistical methods are used to describe the mechanical behavior of ceramics, as the Weibull statistic which is frequently used to describe the variation of mechanical properties $[4,5]$.

Coefficient of thermal expansion (CTE) plays an 
important role in the clinical performance of all-ceramic (metal free) restorations. CTE of porcelain for veneering and core material (metal or ceramic) should be similar to each other to avoid fracture or delamination due to the excessive residual stress in the porcelain. The maximal mismatch between CTE of substructure material and porcelain should be less than $10 \%$. CTE of porcelain glass phase is approximately $9.0 \times 10^{-6}{ }^{\circ} \mathrm{C}^{-1}$ while the conventional dental alloys are approximately $14.0 \times 10^{-6}{ }^{\circ} \mathrm{C}^{-1}$, and the typical CTE of $\mathrm{ZrO}_{2}\left(\mathrm{Y}_{2} \mathrm{O}_{3}\right)$ is $10.5 \times 10^{-6}{ }^{\circ} \mathrm{C}^{-1}$. In porcelains, CTE can be adjusted by addition of leucite that has high CTE, which also improve its mechanical properties [3]. The technique of porcelain layering and ceramic firing used in the application on zirconia-based $\left(\mathrm{ZrO}_{2}-\mathrm{Y}_{2} \mathrm{O}_{3}\right)$ infrastructure have significant effect on final properties of the prostheses. Al-Amleh et al. [6] showed that porcelain thickness and cooling rate are representative in the generation of residual stress between $\mathrm{ZrO}_{2}$ and the porcelain in fast cooling, with 13.1 $\mathrm{MPa}(1 \mathrm{~mm}), 9.5 \mathrm{MPa}(2 \mathrm{~mm})$ and $9.2 \mathrm{MPa}(3 \mathrm{~mm})$ of residual thermal stress, but residual thermal stress was reduced to 4.2-5.6 MPa when the porcelain is slowly cooled, with no statistically significance for porcelain thickness. Meireles et al. [7] did not find difference at $1 \mathrm{~mm}$ porcelainzirconia interface applied under fast and slow cooling. Fabris et al. [8] showed that residual thermal stress between zirconia and the porcelain suffers considerable variations depending on the amount of porcelain layers applied over the prosthesis.

The increasing use of prosthesis with tetragonal zirconia infrastructure stabilized by yttria (Y-TZP), coated by feldspathic ceramic has grown in recent years. However, despite of being observed some rare failure in zirconia structure, the fractures in feldspathic ceramic occur in considerably superior frequency than in traditional metal-ceramic prostheses. According to the sensibility of the final processing effects of porcelain layers in these systems of fixed dental prostheses (FDPs) in their mechanical resistance, the knowledge of mechanical properties in commercial porcelains indicated for application on Y-TZP as well as the analysis of its reliability are important contribution for prostheses design which simulate aesthetics and natural teeth role. The aim of this work is to evaluate the reliability of different dental porcelains indicated for Y-TZP veneering using statistical tools aiming to analysis of mechanical behavior in different commercial materials.

\section{EXPERIMENTAL PROCEDURE}

Processing: four different commercial porcelains for Y-TZP veneering were used in this work. The main properties of the porcelains studied are described in Table I. Porcelain powders, as received, were mixed with the respective modeling aqueous liquid, forming a consistent paste, and inserted into a silicone mold ( $28 \times 5.2 \times 1.6 \mathrm{~mm})$. Bar-shaped specimens were prepared for three-point bending strength test according to ISO 6872-15 standard [13]. Firing schedules were performed according to the manufacturer's instructions, under vacuum according to Table II. In order to minimize the cooling effects on the generation of residual stress, the samples were cooled inside the oven with cooling rate of $5{ }^{\circ} \mathrm{C} / \mathrm{min}$ until room temperature. After sintering, the specimens were machined for dimensions adjusting, as recommended by the ISO $6872-15$ standard ( $22 \times 4$ x $1.2 \mathrm{~mm})$, and polished to the $0.05 \mu \mathrm{m}$ roughness.

Characterization: the relative density of the all fired samples was determined using Archimedes' principle, correlating apparent density with theoretical density. The crystalline phases were determined by X-ray diffraction analysis, using a Shimadzu XRD-6000 diffractometer. The analysis was conducted with $\mathrm{CuK} \alpha$ radiation in the $2 \theta$ range of 20 to $80^{\circ}$, a step width of $0.05^{\circ}$ and an exposure time of $3 \mathrm{~s}$ per position. Mechanical properties: for Vickers hardness and fracture toughness test, the fractured bars, used in the bending strength test, were embedded in acrylic resin

Table I - Properties of dental porcelains studied [applied for $\mathrm{ZrO}_{2}\left(\mathrm{Y}_{2} \mathrm{O}_{3}\right)$, Y-TZP, core] [9-12].

[Tabela I - Propriedades das porcelanas dentárias estudadas [aplicadas sobre $\mathrm{ZrO}_{2}\left(\mathrm{Y}_{2} \mathrm{O}_{3}\right), Y$-TZP] [9-12].]

\begin{tabular}{|c|c|c|c|}
\hline $\begin{array}{l}\text { Commercial } \\
\text { brand }\end{array}$ & $\begin{array}{l}\text { Young's } \\
\text { modulus } \\
\text { (GPa) }\end{array}$ & $\begin{array}{c}\text { CTE } \\
\left(\times 10^{-6}{ }^{\circ} \mathrm{C}^{-1}\right)\end{array}$ & Manufacturer \\
\hline $\begin{array}{l}\text { IPS e.Max } \\
\quad(\mathrm{EM})\end{array}$ & 65 & 9.2 & $\begin{array}{l}\text { Ivoclar Vivadent, } \\
\text { Liechteistein }\end{array}$ \\
\hline VM9 (V9) & 66 & 9.1 & $\begin{array}{c}\text { Vita Zahnfabrik, } \\
\text { Germany }\end{array}$ \\
\hline $\begin{array}{l}\text { Creation } \\
\text { (CR) }\end{array}$ & 60 & 9.5 & $\begin{array}{l}\text { Creation Willi } \\
\text { Geller, Austria }\end{array}$ \\
\hline $\begin{array}{c}\text { Cerabien } \\
\text { ZR (CZR) }\end{array}$ & 62 & 9.2 & $\begin{array}{c}\text { Noritake Dental } \\
\text { Supply, Japan }\end{array}$ \\
\hline
\end{tabular}

Note: global average chemical composition (wt\%): $\mathrm{SiO}_{2}: 60-64 ; \mathrm{Al}_{2} \mathrm{O}_{3}$ : 13-15; $\mathrm{K}_{2} \mathrm{O}: 7-10$; $\mathrm{Na}_{2} \mathrm{O}: 4-6 ; \mathrm{B}_{2} \mathrm{O}_{3}: 3-5$; others: 0-2.

Table II - Firing schedules of porcelains.

[Tabela II - Ciclos de sinterização das porcelanas.]

\begin{tabular}{ccccccc}
\hline $\begin{array}{c}\text { Commercial } \\
\text { porcelain }\end{array}$ & $\begin{array}{c}\text { Preheating } \\
\text { temperature }\left({ }^{\circ} \mathrm{C}\right)\end{array}$ & $\begin{array}{c}\text { Drying } \\
\text { time }(\mathrm{min})\end{array}$ & $\begin{array}{c}\text { Heating rate } \\
\left({ }^{\circ} \mathrm{C} / \mathrm{min}\right)\end{array}$ & $\begin{array}{c}\text { Final temperature } \\
\left({ }^{\circ} \mathrm{C}\right)\end{array}$ & $\begin{array}{c}\text { Holding } \\
\text { time }(\mathrm{min})\end{array}$ & $\begin{array}{c}\text { Cooling rate } \\
\left({ }^{\circ} \mathrm{C} / \mathrm{min}\right)\end{array}$ \\
\hline VM9 & 500 & 6 & 55 & 910 & 1 & \\
E-MAX Zirline & 400 & 4 & 40 & 960 & 1 & 5 \\
Creation & 500 & 6 & 45 & 910 & 1 & 5 \\
CZR & 600 & 5 & 45 & 930 & 4 & \\
\hline
\end{tabular}


and the surface was polished with diamond suspension (1-3 $\mu \mathrm{m})$. Nine Vickers hardness indentations per sample were made in a microhardness tester (Micromet 2100, Buehler) with $500 \mathrm{gf}$ load for $30 \mathrm{~s}$. Fracture toughness was determined by Vickers hardness indentation technique, which is based on the relationship among the Vickers hardness value, cracks that form from each corner of the indentation, and Young's modulus. Fracture toughness was calculated by:

$$
\mathrm{K}_{\mathrm{IC}}=0.016\left(\frac{\mathrm{E}}{\mathrm{H}}\right)^{1 / 2} \frac{\mathrm{P}^{3 / 2}}{\mathrm{C}}
$$

where $\mathrm{K}_{\mathrm{IC}}$ is the fracture toughness $\left(\mathrm{MPa} \cdot \mathrm{m}^{1 / 2}\right.$ ), E is the Young's modulus (GPa), $\mathrm{P}$ is hardness test load $(\mathrm{N}), \mathrm{H}$ is Vickers hardness $(\mathrm{GPa})$ and $\mathrm{C}$ is half the diagonal of indentation crack (m). The 3-point flexural testing was performed using a mechanical testing machine (DL 2000, Emic), with a flexure fixture with span of $20 \mathrm{~mm}$ at $0.5 \mathrm{~mm} / \mathrm{min}$ crosshead speed, applying the Eq. B:

$$
\sigma_{\mathrm{f}}=\frac{3 \mathrm{FL}}{2 \mathrm{bh}^{2}}
$$

where $\sigma_{\mathrm{f}}$ is the bending strength (MPa), $\mathrm{L}$ is the distance between the two supports $(\mathrm{mm}), \mathrm{F}$ is the load at fracture $(\mathrm{N})$, $\mathrm{b}$ is the width of the specimen $(\mathrm{mm}), \mathrm{h}$ is the height of the specimen $(\mathrm{mm})$.

Statistical analysis: one-way ANOVA was used for analysing the mechanical properties, followed by Tukey's honestly significant difference (HSD) post hoc test $(\alpha=0.05)$ applied to determine the difference between the means of bending strength, hardness and IF fracture toughness of the specimens. Statistical analysis was performed with software IBM SPSS Statistics v19.0, IBM. The statistical evaluation of porcelain bending strength was carried out using Weibull statistic [9]. The bi-parameterized Weibull distribution function was used according to:

$$
\mathrm{P}=1-\exp \left\{\left[-\frac{\sigma}{\sigma_{0}}\right]^{\mathrm{m}}\right\}
$$

where P - failure probability, $\mathrm{m}$ - Weibull modulus, $\sigma_{0}$ characteristic strength (MPa), $\sigma$ - bending rupture stress (MPa). Weibull parameters $\mathrm{m}$ and $\sigma_{0}$ were obtained transforming Eq. C into Eq. D and plotting $\ln \ln [1 /(1-\mathrm{P})]$ versus $\ln \sigma$ :

$$
\ln \ln \left[\frac{1}{(1-\mathrm{P})}\right]=\mathrm{m} \ln \sigma-\mathrm{m} \ln \sigma_{0}
$$

The characteristic strength, $\sigma_{0}$, corresponding to $63.2 \%$ of failure probability, was estimated as reference and compared to average strength value. Weibull moduli, m, were determined using adjustment factor 0.908 , according to DIN 843-5 standard [14].

\section{RESULTS AND DISCUSSION}

\section{Porcelain characterization}

The representative X-ray diffraction pattern of porcelain after sintering is shown in Fig. 1. The phase analysis revealed only the presence of the leucite phase in all porcelain analyzed. Besides that, all ceramics presented, after sintering, residual amorphous phase, indicating there was no complete crystallization of the material. Relative density of fired samples is presented in Fig. 2. The results indicated that the firing parameters used allowed the high densification of commercial porcelains, with relative density between $98.5 \%$ and $99.3 \%$ of theoretical density. These results showed almost total elimination of pores during porcelain sintering (firing).

Analyzing X-ray diffractogram in Fig. 1 it can be observed the presence of residual amorphous phase (necessary to produce the translucent effect on the porcelains, allowing to simulate the dental enamel) and partial leucite crystallization, PDF 71-1147. This crystallographic profile was observed in all porcelains studied and indicated there was no complete porcelain crystallization during the firing cycles proposed by manufactures. Similar behaviour was observed in several previous works $[15,16]$. Furthermore, the porcelains used in metal-ceramic or metal-free systems are submitted to several thermal treatment sequences, which promote new and accumulated crystallizations in porcelain matrices. In this work, it was used the final firing temperature expected for dentine application on the prosthesis; however, this knowledge that ceramics suffer repeated thermal treatments

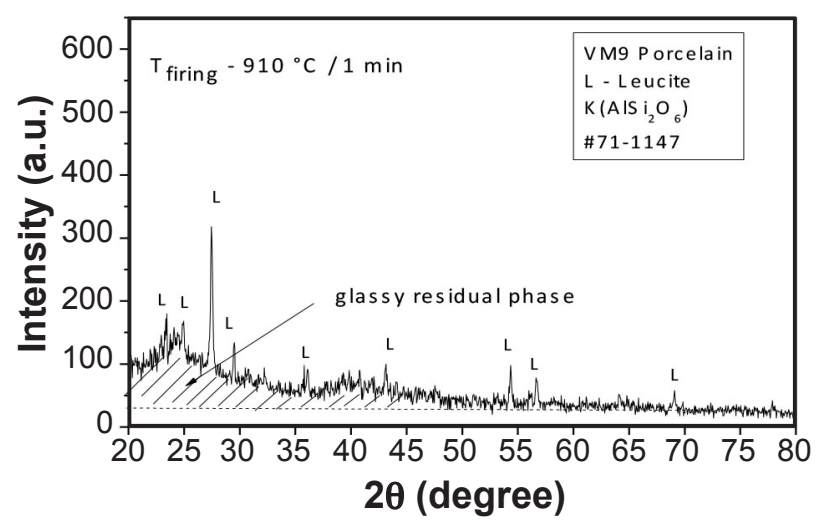

Figure 1: Typical X-ray diffraction pattern of porcelain after firing (VM9, $910^{\circ} \mathrm{C}-1 \mathrm{~min}$ ).

[Figura 1: Difratograma de raios $X$ típica da porcelana após queima (VM9, $\left.\left.910{ }^{\circ} \mathrm{C}-1 \mathrm{~min}\right).\right]$

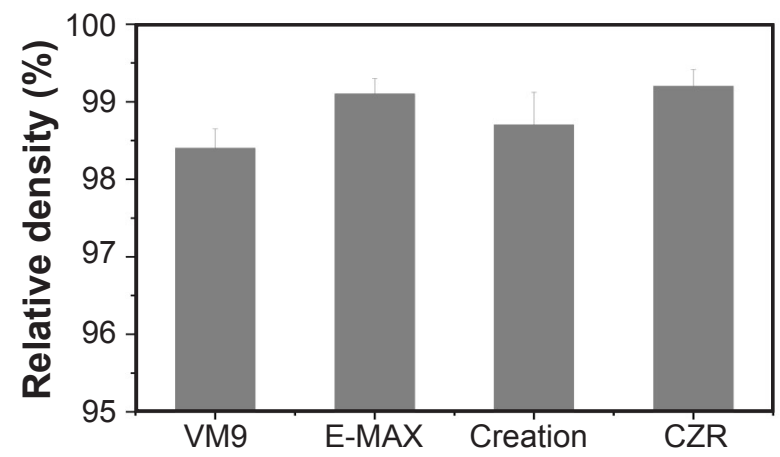

Figure 2: Relative density after porcelains firing.

[Figura 2: Densidade relativa das porcelanas após queima.] 
with crystallization increasing should not be forgotten during the analysis of real mechanical behavior to which the material is submitted in a dental prosthesis.

The results presented in Fig. 2 indicated that the sample submitted to firing at superior final temperature (E-MAX $960{ }^{\circ} \mathrm{C}-4 \mathrm{~min}$ ) showed relative density slightly superior to the ceramics submitted to $910{ }^{\circ} \mathrm{C}-1$ min (VM9 and Creation). The glass transition temperature $\left(\mathrm{T}_{\mathrm{g}}\right)$ of the porcelains ranges from 510 to $740{ }^{\circ} \mathrm{C}$ and varies according to the chemical composition $[17,18]$. Thus, at the firing temperatures used in this work, the viscous flow mechanism allowed the pores removal and ceramic densification simultaneously with the beginning of the porcelain partial crystallization. In any way the densification obtained by the porcelains studied in this work was considered satisfactory because the residual porosity level was very low and, for real cases of porcelain application over zirconia infrastructure, new layers applied to firing allow residual pores elimination mainly through the softening of residual amorphous phase in the porcelain, as showed in Fig. 1.

\section{Mechanical properties}

The results of one-way ANOVA of Vickers hardness, fracture toughness and bending strength are summarized in Table III, and contrast of mean is summarized in Table IV. The analysis by one-way Anova for Vickers hardness was significant $(\mathrm{p}<0.001)$ and the contrast test showed difference among all materials (Table IV). The results indicated that, irrespectively of the of porcelain analyzed, all of them presented hardness values around $500 \mathrm{HV}$, and the statistic significant difference might be resultant of some variation mainly in chemical composition of each porcelain which are realized aiming to suit their CTE to the substrate CTE (infrastructure) to that which is attached. One-way Anova for fracture toughness (Table III) was significant $(\mathrm{p}=0.007)$, and Tukey's contrast test (Table IV) showed that the only found difference was between the lowest nominal value (E-MAX= $\left.1.19 \mathrm{MPa} \cdot \mathrm{m}^{1 / 2}\right)$ and the highest one $\left(\mathrm{CZR}=1.42 \mathrm{MPa} \cdot \mathrm{m}^{1 / 2}\right)$. In general, these results were according to the range of 1.0 and 2.0 MPa.m ${ }^{1 / 2}$ reported in literature $[19,20]$. The low porosity level presented in sintered ceramics, close to $1 \%$, can justify $\mathrm{K}_{\mathrm{IC}}$ results obtained. The standard ISO 6872-15 [13] requires $\mathrm{K}_{\mathrm{IC}}>0.7 \mathrm{MPa} . \mathrm{m}^{1 / 2}$; therefore, these materials meet the minimum necessary for their use as recovering ceramic.

One-way Anova for bending strength was significant $(p<0.001)$, and the Tukey's test (Table IV) showed no significant difference among porcelains, except the porcelain CZR that was less resistant than any other material. These property differences occur among different products, basically according to the different chemical composition of each porcelain, apart from the firing parameters suggested by manufactures, especially final temperature, holding time, and heating and cooling rates. Besides that, other processing parameters also influence final properties, as the characteristics of the oven used and its vacuum application system, as well as the cooling rates indicated for each porcelain. The comparative analysis of bending strength in fired porcelains used on zirconia recovering indicated that three brands have similar statistical values: VM9, E-MAX and Creation. However, all porcelains studied presented values of bending strength superior to the demands of standard ISO $6872(50 \mathrm{MPa})$, for use as covering ceramic over zirconia infrastructure. In this work, during sintering, it was used the same cooling rate for all porcelains. Thus, it can be deduced that the porcelains chemical composition and firing parameters presented in the Table II influenced directly on the porcelains bending resistance. Lastly, these results are correlated to relative density, microstructure, leucite content, chemical composition and the fraction of residual amorphous phase in the porcelains. Comparatively, the porcelain CZR (Noritake) presented average value approximately 20\% inferior related to other materials analyzed. On the other hand, the strength of this porcelain had the lowest standard deviation (4 MPa) indicating that it showed lower variation in the results when compared to standard deviation of other porcelains $($ Creation= 14; E-MAX= 10; VM9=12 MPa).

Fig. 3 presents the failure probability of different porcelains according to local bending strength of each sample analyzed. The graph indicates the probability of a sample

Table III - One-way ANOVA analysis for Vickers hardness, fracture toughness and bending strength in porcelains. [Tabela III - ANOVA a um fator para dureza Vickers, tenacidade à fratura e resistência à flexão das porcelanas.]

\begin{tabular}{|c|c|c|c|c|c|c|}
\hline & & Sum of squares & $\mathrm{DF}^{*}$ & Mean square & $\mathrm{F}^{* *}$ & Sig. \\
\hline \multirow{3}{*}{ Vickers hardness } & Between groups & 5834767.333 & 3 & 1944922.444 & 41.165 & $<0.001$ \\
\hline & Within groups & 2645800.400 & 56 & 47246.436 & & \\
\hline & Total & 8480567.733 & 59 & & & \\
\hline \multirow{3}{*}{$\begin{array}{l}\text { Fracture } \\
\text { toughness }\end{array}$} & Between groups & 0.427 & 3 & 0.142 & 4.418 & 0.007 \\
\hline & Within groups & 1.805 & 56 & 0.032 & & \\
\hline & Total & 2.233 & 59 & & & \\
\hline \multirow{3}{*}{ Bending strength } & Between groups & 2147.251 & 3 & 715.750 & 6.471 & $<0.001$ \\
\hline & Within groups & 6194.436 & 56 & 110.615 & & \\
\hline & Total & 8341.687 & 59 & & & \\
\hline
\end{tabular}


Table IV - Mechanical properties and Tukey test results, where different superscript lowercase in columns indicates significant difference $(\mathrm{p}<0.05)$.

[Tabela IV - Propriedades mecânicas e resultados do teste de Tukey, onde diferentes letras minúsculas sobrescritas em colunas indicam diferença significante $(p<0,05)$.]

\begin{tabular}{cccc}
\hline $\begin{array}{c}\text { Commercial } \\
\text { porcelain }\end{array}$ & $\begin{array}{c}\text { Vickers } \\
\text { hardness } \\
\left(\mathrm{HV}_{500 \mathrm{gf}}\right)\end{array}$ & $\begin{array}{c}\text { Fracture } \\
\text { toughness, } \\
\mathrm{K}_{\mathrm{IC}}\left(\mathrm{MPa} \cdot \mathrm{m}^{1 / 2}\right)\end{array}$ & $\begin{array}{c}\text { Bending } \\
\text { strength, } \\
\sigma_{\mathrm{f}}(\mathrm{MPa})\end{array}$ \\
\hline VM9 & $575 \pm 32^{\mathrm{a}}$ & $1.34 \pm 0.14^{\mathrm{ab}}$ & $75 \pm 12^{\mathrm{a}}$ \\
E-MAX & $544 \pm 13^{\mathrm{b}}$ & $1.19 \pm 0.11^{\mathrm{b}}$ & $73 \pm 10^{\mathrm{a}}$ \\
Creation & $492 \pm 23^{\mathrm{d}}$ & $1.32 \pm 0.20^{\mathrm{ab}}$ & $75 \pm 14^{\mathrm{a}}$ \\
CZR & $515 \pm 12^{\mathrm{c}}$ & $1.42 \pm 0.45^{\mathrm{a}}$ & $62 \pm 4^{\mathrm{b}}$ \\
\hline
\end{tabular}

to be broken in some specific breakage stress if the value is exceeded. From this chart it is also possible to determine the characteristic breakage stress at $63.2 \%$ of failure probability. Weibull diagrams of different porcelains are presented in Fig. 4. The results of Weibull analysis results were applied to bending strength results. In Table V, Weibull analysis results such as final Weibull modulus (m), adjusted to the number of samples, characteristic strength of each material $\left(\sigma_{0}\right)$, and the interpolation correlation coefficient ( $\mathrm{R}$, linear adjustment) used to determine Weibull modulus are presented. The linear correlation coefficients $(\mathrm{R})$ of all linear adjustments were close to 1 , indicating that the breakage stress data were well adjusted according to Weibull analysis $[5,21]$ allowing to guarantee the Weibull modulus values reliability, which were submitted to the adjustment coefficient according to the number of samples. In general, the Weibull modulus strongly depends on several ceramic processing conditions, which can interfere in microstructure, purity and pores distribution in the material, among others. All of these aspects can lead to variations in Weibull modulus that can be from $m=3$ to 15 , which means that for a Weibull modulus of 15 specimens presents lower dispersion of bending strength values in comparison to groups of samples of $m=3$, a typical characteristic of materials with low reliability. Quinn [22] describes that a modulus $m=10$ indicates a ceramic material of good reliability for structural applications.

Analyzing Fig. 4, the porcelains used for zirconia-based ceramic recovering (VM9, E-MAX and Creation) showed Weibull modulus varying from $m=5.7$ to 7.1 . CZR porcelains showed $\mathrm{m}=13.6$, superior to the other analyzed brands (VM9, E-MAX, Creation). The superior reliability evaluation of this material must be associated to the bending strength results which demonstrate considerably lower values compared to other brands. From this analysis it can be seen that CZR porcelain showed lower bending strength than the others, however the reliability of these ceramics was superior to all other brands studied. From this finding, the use or not of this material must be decided considering mainly the kind of prosthesis and mechanical efforts the prostheses are submitted during chewing movements. Similarity among all porcelains in the bending strength test agrees with the study

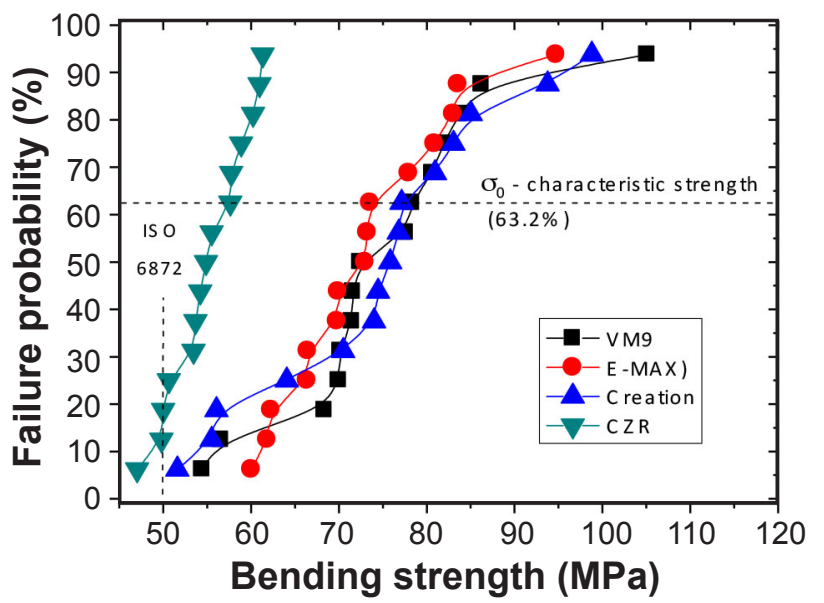

Figure 3: Failure probability comparative among different dental porcelains.

[Figura 3: Comparação da probabilidade de falhas entre as diferentes porcelanas dentárias.]

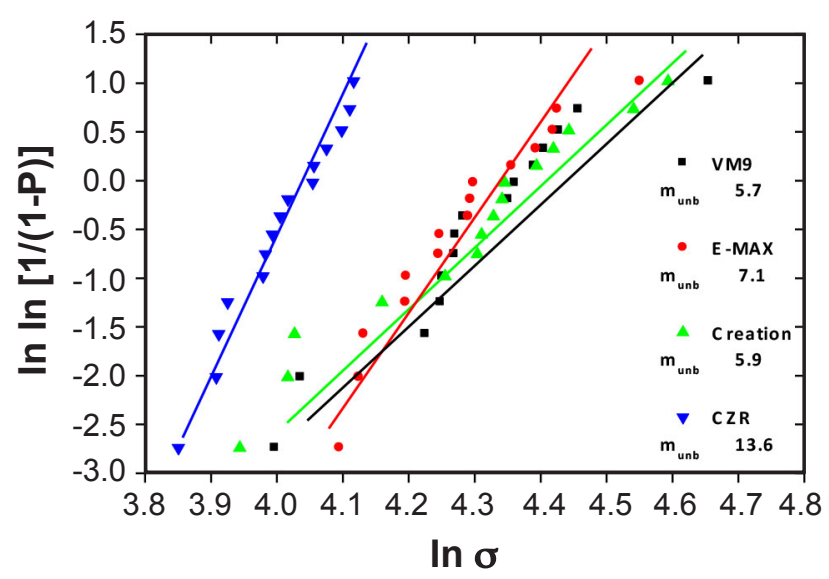

Figure 4: Weibull diagram for different dental porcelains.

[Figura 4: Diagrama de Weibull para as diferentes porcelanas dentárias.]

of Fischer et al. [23] who found values of veneering porcelain for Y-TZP rather similar or even lower than those for metalceramic cores. However, it is reported larger failure rates in all-ceramic restorations [24]. Y-TZP/porcelain restorations may behave differently from metal-ceramic after firing. Residual stresses developed during cooling in metal-ceramic restorations may be relaxed by elastic or plastic deformation of the core, which can reduce the porcelain fracture under clinical loads. In contrast, Y-TZP is more rigid than metallic cores and the stresses formed are not able to relax to the substructure deformation.

It must be emphasized that bending strength analyzes were realized in monolithic porcelains and not in doublelayered porcelain/zirconia samples, representing a limitation in the results presented faced to real clinical cases, because these results do not consider residual thermal stresses in the interface, not even the real surface roughness among the layers generated by the several porcelain applications. These phenomena have been studied in different works 
Table V - Weibull parameters of bending stress of the porcelains. [Tabela V - Resistência à flexão e parâmetros de Weibull das porcelanas.]

\begin{tabular}{ccccc}
\hline $\begin{array}{c}\text { Specimen } \\
\text { type }\end{array}$ & $\begin{array}{c}\text { Characteristic } \\
\text { strength, } \sigma_{0}^{*}(\mathrm{MPa})\end{array}$ & $\begin{array}{c}\text { Weibull } \\
\text { modulus, } \mathrm{m}\end{array}$ & $\begin{array}{c}\text { Adjusted Weibull } \\
\text { modulus, } \mathrm{m}_{\text {unb }}\end{array}$ & $\begin{array}{c}\text { Correlation } \\
\text { coefficient, } \mathrm{R}\end{array}$ \\
\hline VM9 & 47.5 & 6.3 & 5.7 & 0.955 \\
E-MAX & 43.2 & 7.9 & 7.1 & 0.957 \\
Creation & 47.8 & 6.4 & 5.9 & 0.981 \\
CZR & 38.9 & 15.0 & 13.6 & 0.987 \\
\hline - 63.2\% failure probability. & & &
\end{tabular}

$[25,26]$ and interfere negatively in the real mechanical behaviour of dental prosthesis. On the other hand, the specimen processing standardization, as well as bending testing, strictly following the demands of ISO 6872 standard, allow a comparative analyzes among different porcelains without external parameters interference. Silicate glasses generally form the matrix phase in feldspathic porcelains whose $\mathrm{K}_{\mathrm{IC}}$ values are typically in the range $0.7-1 \mathrm{MPa} \cdot \mathrm{m}^{1 / 2}$. Then, porcelain toughness depends mainly on the crystalline phase [27]. The porcelain microstructure can affect strongly its mechanical properties and porcelains with higher amounts of leucite are more resistant to the fast crack propagation due to the phenomenon of crack deflection around leucite crystals [28]. Nevertheless, the effect of leucite used as crystalline phase may not be effective to improve the resistance to slow crack growth [29]. Thus, the long-term survival time of dental ceramics is not determined only by their initial strength and toughness [30]. Considering that porcelain for metal cores have higher CTE than porcelains for Y-TZP and that the CTE adjustment is made by adding leucite crystals, it is expected high mechanical performance of porcelains for metal cores. However, the fracture of porcelain in clinical use is complex in terms of the variability among patients' bit force, diet and oral parafunctional habits. A fatigue test simulating the oral environment conditions would be useful to the fracture phenomena understanding.

\section{Fracture mechanics in dental porcelains}

According to the linear elastic fracture mechanics, the mechanical strength of a material is mathematically defined by the Irwin equation, given by:

$$
\sigma_{\mathrm{f}}=\frac{\mathrm{K}_{\mathrm{IC}}}{\mathrm{Y} \cdot \mathrm{a}^{1 / 2}}
$$

where $\mathrm{K}_{\mathrm{IC}}$ is the fracture toughness, a the natural flaw size, and $\mathrm{Y}$ the calibration factor ( $\mathrm{Y}=1.985$, adapted from [18]). The fracture toughness can also be associated with the fracture energy by:

$$
\mathrm{K}_{\mathrm{IC}}=\sqrt{2 \cdot \mathrm{E} \cdot \gamma_{\mathrm{i}}}
$$

where $\mathrm{E}$ is the Young's modulus and $\gamma_{\mathrm{i}}$ the fracture energy of the material. Those equations determine that the mechanical strength of a ceramic material can be characterized by three factors: flaw size, Young's modulus and fracture energy.
Based on classical equations from fracture mechanics for fragile materials it is possible to calculate the fracture energy and the critical flaw size for the porcelains breakage. Table VI presents calculated values, using the experimental results obtained in this work.

Analyzing Table VI, it can be observed that the calculated flaw size varied between 66 and $136 \mu \mathrm{m}$ depending on the porcelain analyzed. These values indicated that some superficial processing flaw, as a pore, with dimensions superior to the calculated ones, can lead to porcelain fracture, if the applied stress is around the rupture modulus in the surface, within tensile loading. The superficial fracture energy in glass, at room temperature, has relatively low values when compared to crystalline ceramics. These values are usually between 3 and $6 \mathrm{~J} / \mathrm{m}^{2}$ [31] depending mainly on the glass chemical composition, which changes the properties of its chemical bonds and, consequently, its Young's modulus. The crystallization process in some glasses, as well as in the porcelains studied in this work, tends to increase the fracture energy due to the structural organization resulting from the crystallization with leucite grain generation [32]. The porcelains studied presented theoretical fracture energy between 10.5 and $16.3 \mathrm{~J} / \mathrm{m}^{2}$, considerably superior to conventional glasses, but low when compared to structural ceramics.

The X-ray diffractogram presented in Fig. 1 indicated, after firing, leucite presence apart from considerable amount of amorphous phase (vitreous). The re-sintering stages (re-firing) whose layers will be submitted to, during prostheses manufacturing, lead to an accumulated increase in crystallization of initial layers causing a higher crystallization level. Thereby the fracture energy tends to increase, raising breakage modulus and reducing the critical flaw size so that fracture can occur. This way, the critical flaw size in

Table VI - Critical flaw size and fracture energy for dental porcelains studied.

[Tabela VI - Propriedades mecânicas, tamanho crítico do defeito e energia de fratura para as porcelanas estudadas.]

\begin{tabular}{ccc}
\hline $\begin{array}{c}\text { Specimen } \\
\text { type }\end{array}$ & $\begin{array}{c}\text { Critical calculated } \\
\text { flaw size }(\mu \mathrm{m})\end{array}$ & $\begin{array}{c}\text { Fracture energy, } \\
\gamma_{\mathrm{i}}(\mathrm{J} / \mathrm{m})\end{array}$ \\
\hline VM9 & 79 & 13.6 \\
E-MAX & 66 & 10.5 \\
Creation & 90 & 16.3 \\
CZR & 136 & 14.0 \\
\hline
\end{tabular}


recovering porcelain can be partially controlled in order to, eventually, improve its performance, mainly by controlling the crystallization and microstructure of this glass-ceramic [32, 33]. For porcelain property optimization, the main processing parameters to be controlled must be: a) those related to porcelain processing: thickness and uniformity of porcelain layer over zirconia infrastructure, apart from firing parameters as temperature, holding time and cooling rates; b) superficial finishing, absence of superficial pores and elimination of stress concentration points; c) special highlights for more external layers of the prosthesis, aiming elimination of residual stress and increase of crystallization level in order to increase fracture energy and bending resistance of these layers.

\section{CONCLUSIONS}

Commercial porcelains were sintered according to manufacturer's instructions and presented relative density superior to $98.5 \%$ and hardness was different among all ceramics, varying from 491 to $575 \mathrm{HV}$. The materials presented fracture toughness between 1.19 and $1.42 \mathrm{MPa} \cdot \mathrm{m}^{1 / 2}$, and only a difference was found between the studied materials. Bending strength from the lowest mean value of CZR to the other porcelains that had not significant difference each other. Irrespectively of statistical significance the achieved results meet the standard demands for ceramic recovering (ISO 6872). Weibull statistical studies indicated that the porcelains presented variations in Weibull modulus (m) with values between 6.3 and 15 . These variations were related to crystallographic and compositional characteristics for each porcelain. Theoretical fracture energy from 10.5 to $16.3 \mathrm{~J} / \mathrm{m}^{2}$ calculated in this work possibly can be improved, because the residual amorphous phase in the porcelains after firing can suffer new crystallization during successive firing cycles to which the porcelain is submitted during manufacturing of metal free prostheses.

\section{ACKNOWLEDGMENTS}

The authors would like to thank Professor Kurt Strecker from UFSJ - Universidade Federal de São João Del Rey, for the collaboration in Weibull statistical results and to FAPESP - Fundação de Amparo a Pesquisa do Estado de São Paulo for financial support.

\section{REFERENCES}

[1] B.E. Pjetursson, I. Sailer, N.A. Makarov, M. Zwahlen, D.S. Thoma, Dent. Mater. 31 (2005) 624.

[2] K. Zeng, A. Oden, D. Rowcliffe, Int. J. Prosthodont. 11 (1998) 183.

[3] K. Anusavice, C. Shen, H.R. Rawls, Phillips' science of dental materials, $12^{\text {th }}$ ed. (2012).

[4] D. Liu, J.K.-H. Tsoi, E.H.-N. Pow, H.M. Wong, Int. J. Adhes. Adhes. 62 (2015) 18.
[5] J.B. Quinn, G.D. Quinn, Dent. Mater. 26 (2010) 135.

[6] B. Al-Amleh, J.N. Waddell, K. Lyons, M.V. Swain, Dent. Mater. 30 (2014) 271.

[7] P.D. Meirelles, Y.O. Spigolon, M. Borba, P. Benetti, Dent. Mater. 32 (2016) e382.

[8] D. Fabris, J.C.M. Souza, F.S. Silva, M. Fredel, J. MesquitaGuimarães, Y. Zhang, B. Henriques, Ceram. Int. 43 (2017) 3670.

[9] http://www.creation-willigeller.com

[10] http://vikadent.lt

[11] http://www.kuraraynoritake.com

[12] http://www.ivoclarvivadent.com

[13] International Organization for Standardization, ISO 6872,

"Dentistry - ceramic materials", $4^{\text {th }}$ ed. (2015).

[14] Deutsches Institut für Normung, DIN EN 843-5, "Advanced technical ceramics - mechanical properties of monolithic ceramics at room temperature - part 5: statistical analysis" (2007).

[15] M.M. Barreiro, O. Rlesgo, E.E. Vicente, Dent. Mater. 5, 1 (1989) 51.

[16] J.R. Mackert Jr., A.L. Williams, J.W. Ergle, C.M. Russell, Dent. Mater. 16 (2000) 426.

[17] C. Fredericci, H.N. Yoshimura, A.L. Molisani, M.M. Pinto, P.F. Cesar, Ceram. Int. 37 (2011) 1073.

[18] A. De Noni Jr., D. Hotza, V.C. Soler, E.S. Vilches, J. Eur. Ceram. Soc. 28 (2008) 2463.

[19] A.S. Rizkalla, D.W. Jones, Dent. Mater. 20 (2004) 198.

[20] H.N. Yoshimura, P.F. Cesar, W.G. Miranda Jr., C.C. Gonzaga, C.Y. Okada, H. Goldenstein, J. Am. Ceram. Soc. 88, 6 (2005) 1680.

[21] W. Weibull, J. Appl. Mech. (1958) 293.

[22] G.D. Quinn, in: Engineered materials handbook, vol. 4, ASM Int., Metals Park (1991) 585.

[23] J. Fischer, B. Stawarczyk, C.H. Hammerle, J. Dent. 36 (2008) 316.

[24] I. Sailer, B.E. Pjetursson, M. Zwahlen, C.H. Hammerle, Clin. Oral Implants Res. 18, 3 (2007) 86.

[25] D. Longhini, C.O.M. Rocha, I.S. Medeiros, R.G. Fonseca, G.L. Adabo, Braz. Dent. J. 27, 5 (2016) 524.

[26] A.A. Almeida Junior, D. Longhini, P.A. Suzuki, S. Ribeiro, C. Santos, G.L. Adabo, Mater. Res. 20,5 (2017) 1418. [27] R. Morena, P.E. Lockwood, C.W. Fairhust, Dent. Mater. 2 (1986) 58.

[28] P.F. Cesar, H.N. Yoshimura, W.G. Miranda Junior, C.Y. Okada, J. Dent. 33 (2005) 721.

[29] P.F. Cesar, F.N. Soki, H.N. Yoshimura, C.C. Gonzaga, V. Styopkin, Dent. Mater. 24 (2008) 1114.

[30] B. Taskonak, G.A. Borges, J.J. Mecholsky Jr., K.J. Anusavice, B.K. Moore, J. Yan, Dent. Mater. 24 (2008) 1149.

[31] S.M. Wiederhorn, J. Am. Ceram. Soc. 52, 2 (1969) 99.

[32] R.W. Rice, S.W. Freiman, J.J. Mecholsky Jr, J. Am. Ceram. Soc. 63, 3-4 (1980) 129.

[33] H. Awaji, T. Matsunaga, S.M. Choi, Mater. Trans. 47, 6 (2006) 1532.

(Rec. 13/11/2017, Rev.01/03/2018, Ac.07/04/2018) 